Hydrology and Earth System Sciences, 6(3), 497-505 (2002) C EGS

\title{
Effect on nitrate concentration in stream water of agricultural practices in small catchments in Brittany : I. Annual nitrogen budgets
}

\author{
L. Ruiz, S. Abiven, P. Durand, C. Martin, F. Vertès and V. Beaujouan \\ Institut National de la Recherche Agronomique, UMR Sol, Agronomie et Spatialisation, 4 rue de Stang Vihan, 29000 Quimper, France
}

Email for corresponding author: ruiz@rennes.inra.fr

\begin{abstract}
The hydrological and biogeochemical monitoring of catchments has become a common approach for studying the effect of the evolution of agricultural practices on water resources. In numerous studies, the catchment is used as a "mega-lysimeter" to calculate annual input-output budgets. However, the literature reflects two opposite interpretations of the trends of nitrate concentration in streamwater. For some authors, essentially in applied studies, the mean residence time of leached nitrate in shallow groundwater systems is much less than one year and river loads reflect annual land use while for others, nitrate is essentially transport limited, independent of soil nitrate supply in the short term and annual variations reflect changes in climatic conditions. This study tests the effect of agricultural land-use changes on inter-annual nitrate trends on stream water of six small adjacent catchments from 0.10 to $0.57 \mathrm{~km}^{2}$ in area, on granite bedrock, at Kerbernez, in Western Brittany (France). Nitrate concentrations and loads in streamwater have been monitored for nine years (1992 to 2000) at the outlet of the catchments. An extensive survey of agricultural practices from 1993 to 1999 allowed assessment of the nitrogen available for leaching through nitrogen budgets. For such small catchments, year-to-year variations of nitrate leaching can be very important, even when considering the 'memory effect' of soil, while nitrate concentrations in streamwater appear relatively steady. No correlation was found between the calculated mean nitrate concentration of drainage water and the mean annual concentration in streams, which can even exhibit opposite trends in inter-annual variations. The climatic conditions do not affect the mean concentration in streamwater significantly. These results suggest that groundwater plays an important role in the control of streamwater nitrate concentration.
\end{abstract}

Keywords: nitrate, diffuse pollution, agricultural catchment, nitrogen budget, leaching, Kerbernez catchments.

\section{Introduction}

The intensification of agriculture is the main cause of the increase in nitrate concentration in many rivers in temperate countries over recent last decades. Comparisons of nitrogen concentrations in catchments covering very contrasted land uses showed a relationship between dominant land use and the mean nitrogen concentration in the stream: concentrations increased from woodland to grassland and arable land (Neill, 1989; Edwards et al., 1990; Reynolds and Edwards 1995; Magdoff et al., 1997).

The effect of various agricultural practices and nitrogen management is well documented at the plot or field scale, and many models simulate the nitrogen concentration of drainage water under various agricultural land uses, through a dynamic description of the soil-plant-atmosphere system
(Leonard et al., 1987; Bradbury et al., 1993; Brisson et al., 1998) or through a simple nitrogen budget (Simon and Le Corre, 1992; Gaury, 1992; Chauvin et al., 1997; Farruggia et al., 1997). Catchments were used as "mega-lysimeters" to calculate annual input-output budgets and to predict nitrogen loads in streams by aggregation of nitrogen loads from fields. This assumes, often implicitly, that the hydrological and hydrochemical response time of the catchment stream to changes in agricultural practices is about one year (Burt and Arkell, 1987; Johnes, 1996; Ruiz et al., 2002a). Although the amount and quality of the data collected and the methods of deriving drainage water concentration from agricultural practices vary widely from one study to another, acceptable relationships between the calculated concentration in drainage water and the 
measured concentration in streams are frequently found (Gaury and Benoit, 1992; Johnes, 1996; Aurousseau et al., 1996; Billen et al., 1998; Turpin et al., 2000). However, the amount and quality of the data used for these studies and the methods of deriving drainage water concentrations from agriculture practices vary widely from one study to another. Differences have been attributed either to biotransformations during the transfer to the river or in the stream (Aurousseau et al., 1996; Ruiz et al., 1999) or to the buffering effect of the soil through the turn over of organic matter (Mariotti, 1997; Worral and Burt, 2001); the last named authors link the variations of nitrogen outputs to variations in grassland areas (i.e. organic storage). Another possible assumption is that nitrate may have a long residence time in a catchment due to hydrological processes. Evidence from isotopic studies (Bölke and Denver, 1995), from groundwater monitoring (Steinheimer et al., 1998; Molénat et al., 2002) or from fractal analysis of stream chloride and sodium (Kirchner et al., 2000; Neal and Kirchner, 2000) suggests that even shallow groundwater may constitute an important reservoir for solutes. Thus, nitrate losses would be essentially transport-limited and stream concentration would be determined by a source little influenced by annual variations in the soil nitrate supply (Trudgill et al., 1991) so that the annual mean concentration should be almost constant. However, some authors have observed that the annual concentration increases when the rainfall increases (Creed et al., 1996; Creed and Band, 1998), which has been interpreted as a "flushing" of the N-rich upper layers of the soils.
This short review shows that, although the agricultural inputs of nitrogen can be related to streamwater concentrations on a regional scale, for large catchments and slowly varying systems, the quantitative link between the two may not be warranted on an annual basis. In the present study, agricultural practices and streamwater quality were monitored in a set of small agricultural catchments for several years. This paper focuses on the nitrogen budgets of the catchments on an annual basis, while the companion paper (Ruiz et al., 2002b) discusses the hydrological processes inferred by the analysis of the seasonal variations of streamwater nitrate concentrations. This study also illustrates the large nitrogen fluxes involved in intensively farmed European regions; Brittany, where the catchments are located, is one of the main agricultural regions in Europe for dairy, pig and poultry production.

\section{Study site}

The Kerbernez site (Fig. 1), described by Vertès et al. (1996), covers an area of $1.28 \mathrm{~km}^{2}$ in south-western Brittany $\left(47^{\circ}\right.$, $\left.35^{\prime} \mathrm{N} ; 117^{\circ} 52^{\prime} \mathrm{E}\right)$. Elevations range from 10 to $55 \mathrm{~m}$ a.s.l.. The slopes are generally less than $7 \%$ but, locally, slopes steeper than $15 \%$ are observed. The different streams join the Odet river 10 kilometres before it flows into the Atlantic.

The climate is oceanic. Mean annual temperature is $11.4^{\circ} \mathrm{C}$ with a minimum of $6.1{ }^{\circ} \mathrm{C}$ in January and a maximum of $17.6^{\circ} \mathrm{C}$ in July. The mean annual rainfall for the last decade was $1146 \mathrm{~mm}$; it ranged from less than $900 \mathrm{~mm}(1991 / 1992$ and 1996/1997) to more than $1400 \mathrm{~mm}(1993 / 1994$ and

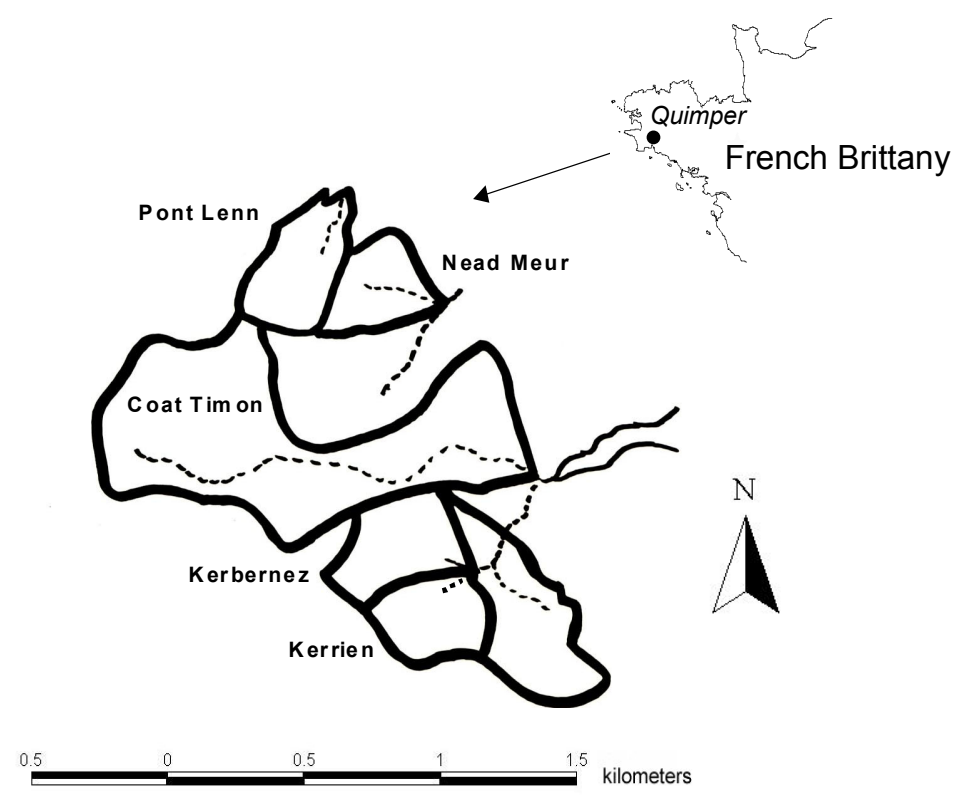

Fig 1. location map of the Kerbernez study site and of the different catchments 
1994/1995). The rainiest seasons are autumn and winter. Mean annual Penman potential evapotranspiration (PET) is $616 \mathrm{~mm}$.

The bedrock belongs to the same geological unit, leucogranodiorite of Plomelin (paleozoïc, Béchennec and Hallégouët, 1999) but it cannot be considered as impervious, and some water is probably lost by deep percolation through rock fractures and fissures. The upper part of this granite is weathered to depths of 1 to more than $20 \mathrm{~m}$ (Montoroi et al., 2001). Soils are mainly sandy loam (distric cambisol, FAO classification). The upper horizon $(0-20 \mathrm{~cm})$ is very rich in organic matter ( 4.5 to $6 \%$ ). The soil depth was surveyed throughout the site, and the average value is $0.8 \mathrm{~m}$. Soils are well drained except in the relatively narrow bottomlands where hydromorphic soils are found.

Land use is predominantly agricultural (77\%). The site is used by seven breeding farms, one of them owning $80 \%$ of the agricultural lands. Animals are mainly dairy cows and breeding sows. Grazed grasslands occupy about half the useable agricultural area. Most arable fields support alternately maize and cereals and are farmed intensively, including importation of pig slurry and cattle manure. Most of the grasslands (pure grass or grass/clover leys) are intensively grazed by dairy cows. The non-cultivated area is occupied by forest, roads or housing.

\section{Material and methods}

The catchment network consists of six first-order basins and one second order basin (Fig 1): Nead Meur $\left(0.135 \mathrm{~km}^{2}\right)$, Pont Lenn $\left(0.117 \mathrm{~km}^{2}\right)$, Coat Timon $\left(0.57 \mathrm{~km}^{2}\right)$, Le Puits $\left(0.37 \mathrm{~km}^{2}\right)$, Kerbernez $\left(0.12 \mathrm{~km}^{2}\right)$ and Kerrien $\left(0.095 \mathrm{~km}^{2}\right)$, the last two being subcatchments of Le Puits.

An automatic weather station located on the site records hourly rainfall and variables necessary to estimate daily PET from the Penman formula. Water has been sampled at the outlet of each catchment since 1991, two to four times a month, and analysed for nitrate by colourimetry. Samples collected during or just after a storm event were discarded to avoid any underestimation of base flow concentration. All outlets are equipped with $\mathrm{V}$-notch weirs and stream water levels at outlets were measured at the time of sampling. Since 1997, the water level at the outlet of the Le Puits catchment has been recorded continuously by an automatic data logger. For the previous years, it was estimated with a simple rain/ discharge linear store model. In the text, the mean annual streamwater nitrate concentration refers to a dischargeweighted mean.

The annual amount of drainage water is calculated for each catchment, using averaged soil depth and water retention capacity, with the model of Burns (Burns, 1974) and results proved consistent with drainage volumes measured on the same site with lysimeters (Simon and Le Corre, 1996).

An extensive survey of agricultural practices was carried out on every field of the site to calculate agricultural nitrogen budgets. Data of cropping systems, amount of chemical fertilisers, amount and quality of slurry and manure inputs, proportion of legumes in grasslands, cattle grazing management and crop yields were collected from 1993 to 1999. Two types of budget were calculated. Firstly, a simple 'gross budget' was derived from the total annual inputs and outputs of nitrogen on soils considered as black boxes. A similar approach was developed by Benoit (1992) with the 'Bascule' model. Inputs are organic and chemical fertilisers and animal excreta during the grazing periods, while outputs are plant exportations and herbage intake by cows. This simple budget minimises the errors due to hypotheses on the internal cycle of nitrogen in soil. However, by neglecting the 'memory effect' of soils, it probably overestimates yearto-year variations of nitrogen excess. Secondly, a 'corrected budget' was calculated using the model proposed by COMIFER (1996), a decision-making tool for the evaluation of fertilisation requirements by crops. Parameterisation of the model is based on regional references (Chauvin et al., 1997). The differences with the 'gross budget' are:

- Delayed effects of organic inputs as well as gaseous losses during spreading are taken into account. The proportions of $\mathrm{N}$ volatilised are $15 \%$ for pig slurry, $5 \%$ for cattle manure and 5\% for animal returns during grazing. The proportions of $\mathrm{N}$ available during the first year, the second year and the third year are respectively $60 \%, 15 \%$ and $10 \%$ for pig slurry, $35 \%, 25 \%$ and $15 \%$ for cattle manure, and $60 \%, 15 \%$ and $10 \%$ for animal returns during grazing. Any $\mathrm{N}$ remaining is assumed to be immobilised permanently in stable soil organic matter.

- Long-term field experiments and lysimetric studies at the site showed that the annual amount of net $\mathrm{N}$ mineralisation from soil organic matter varied with land use (Simon and Le Corre, 1992), and corresponded to $90 \mathrm{~kg} \mathrm{~N} \mathrm{ha}^{-1}$ for maize, $50 \mathrm{~kg} \mathrm{~N} \mathrm{ha}^{-1}$ for cereals and a net immobilisation of $50 \mathrm{~kg} \mathrm{~N}$ ha $^{-1}$ for grassland. When grassland is ploughed, the mineralisation was assumed to reach $250 \mathrm{~kg} \mathrm{~N} \mathrm{ha}^{-1}$ for the current year and $100 \mathrm{~kg}$ $\mathrm{N} \mathrm{ha}^{-1}$ the following year (Vertès et al., 2001).

- Symbiotic fixation, essentially due to white clover/ ryegrass associations, where evaluated from the proportion of the legume, i.e. $30 \mathrm{~kg} \mathrm{~N} \mathrm{ha}^{-1}$ per ton of clover dry matter.

- Annual atmospheric deposition of nitrogen was fixed at $15 \mathrm{~kg} \mathrm{~N} \mathrm{ha}^{-1}$. 
- An average value of $10 \mathrm{~kg} \mathrm{~N} \mathrm{ha}^{-1}$ lost by denitrification was assumed for agricultural soils (Hénin, 1980).

These budgets are a rough estimate of the nitrogen cycle in such agrosystems: a more precise assessment would require direct measurements or simulation with a dynamic crop and soil model. However, as a first approximation, the amount of $\mathrm{N}$ available for leaching is assumed to equal the excess $\mathrm{N}$ given by the budget (Vertès and Decau, 1992). Since the drainage amount was never below $400 \mathrm{~mm} \mathrm{yr}^{-1}$ during the study period, and the soil retention capacity is less than 200 $\mathrm{mm}$, all the nitrogen potentially available for leaching was assumed to be leached during the current year.

Positive budgets were then aggregated in each catchment for all the fields, to give a mean amount of excess $\mathrm{N}$ at the catchment scale. Finally, the mean annual concentration of drainage water was calculated as the ratio of the total $\mathrm{N}$ available for leaching at the beginning of winter and the amount of drainage water in the following draining period (usually from October to April).

\section{Results}

The catchments show marked differences in terms of mean nitrate concentration in stream water, from $25 \mathrm{mg} \mathrm{NO}_{3} \mathrm{l}^{-1}$ for Nead Meur to $76 \mathrm{mg} \mathrm{NO}_{3} \mathrm{l}^{-1}$ for Kerbernez. However, for a given catchment, year-to-year variations are small, with coefficients of variation ranging between 6 and 13\%. Figure 2 shows that the nitrate concentration in streamwater is independent of the annual amount of drainage water: even when the correlation seems significant, the gradient is very close to zero and neither dilution nor 'flushing' effect is apparent from this data set.

Considering the whole site, land use was constant throughout the seven years of the study. About $50 \%$ of the farm area is grassland, essentially temporary, and the area of white clover/ryegrass mixture increased from 5 to $10 \%$ during the period. Maize and cereals each cover about $25 \%$ of the farm area. Some other crops (field vegetables, rape, etc.) cover only a small part of the surface each year. Also, excess $\mathrm{N}$ for the whole site is relatively constant: from the 'gross budget', annual $\mathrm{N}$ excess is about $120 \mathrm{~kg}$ per hectare of useable farm area; inputs represent $240 \mathrm{~kg} \mathrm{~N} \mathrm{ha}^{-1}$, coming from mineral fertilisation (36\%), animal returns (35\%), slurry ( $17 \%)$ and manure (12\%), while average plant export is $120 \mathrm{~kg} \mathrm{~N} \mathrm{ha}{ }^{-1}$. In the 'corrected budget', $\mathrm{N}$ surplus is slightly greater $\left(140 \mathrm{~kg} \mathrm{~N} \mathrm{ha}^{-1}\right)$; total inputs represent 265 $\mathrm{kg} \mathrm{N} \mathrm{ha}^{-1}$ of the useable farm area, $22 \%$ of it coming from delayed effects of organic fertilisers.

Beside this relative stability, large year-to-year variations in land use and nitrogen excess occur at the catchment scale, as illustrated in Fig. 3 for the years 1995 and 1996. These variations are due mainly to crop rotations or grassland ploughing. Table 1 shows that the annual amount of nitrogen available for leaching as calculated with the 'corrected budget' is much more variable at the catchment scale than at the whole site scale.

Since the annual amount of drainage water is also highly variable (Table 1), the calculated values of mean nitrogen concentration in drainage water vary widely, from 10 to 130 $\mathrm{mg} \mathrm{NO}{ }_{3} 1^{-1}$. For a given catchment, these concentrations exhibit large year-to-year variations, with coefficients of variation ranging between 25 and $70 \%$.

Figure $4 \mathrm{a}$ shows the lack of correlation between the annual mean concentration of nitrate in stream water and that in drainage water, when the latter is calculated from 'gross budgets'. This figure also shows that nitrate concentrations in the streamwater vary much less than in the drainage water. This suggests that the variation of nitrate concentration in drainage water is buffered at the catchment scale. One reason for this buffering could be the 'memory effect' due to the immobilisation and mineralisation of soil organic matter. Figure $4 \mathrm{~b}$ shows that calculating nitrate concentration of drainage water from a 'corrected budget', supposedly to account for delayed effects of organic inputs and $\mathrm{N}$ storage in grasslands, neither reduces the variability significantly nor improves the correlation with nitrate concentration in streamwater.

The trends of nitrate concentration in streamwater are compared to the concentration calculated from the 'corrected budget' for the six catchments throughout the study period (Fig. 5). Once again, the $\mathrm{N}$ concentration in drainage water appears more variable than that in the streamwater. Even exceptional annual increases in concentration in drainage water, due to either high $\mathrm{N}$ excess (generally induced by grassland ploughing) or a low amount of drainage, do not lead to any significant increase in streamwater nitrate concentration. Moreover, in two of the catchments, Kerbernez and Le Puits, the excess $\mathrm{N}$ increases over the period while the concentration in the stream decreases.

The results also show that, every year, nitrogen is stored in three of the catchments (Coat Timon, Pont Lenn, Kerrien) while Kerbernez seems to lose nitrogen. The $\mathrm{N}$ budgets of the other two catchments are roughly balanced, with storage in dry years and release in wet years. These observations must be treated with caution, owing to the uncertainty of the agricultural budgets and of the catchment water balance. However, this suggests that the discrepancy between input and output is not due to a systematic error or to a single sink process such as nitrogen retention by riparian zones. 
Effect on nitrate concentration in stream water of agricultural practices : I. Annual nitrogen budgets
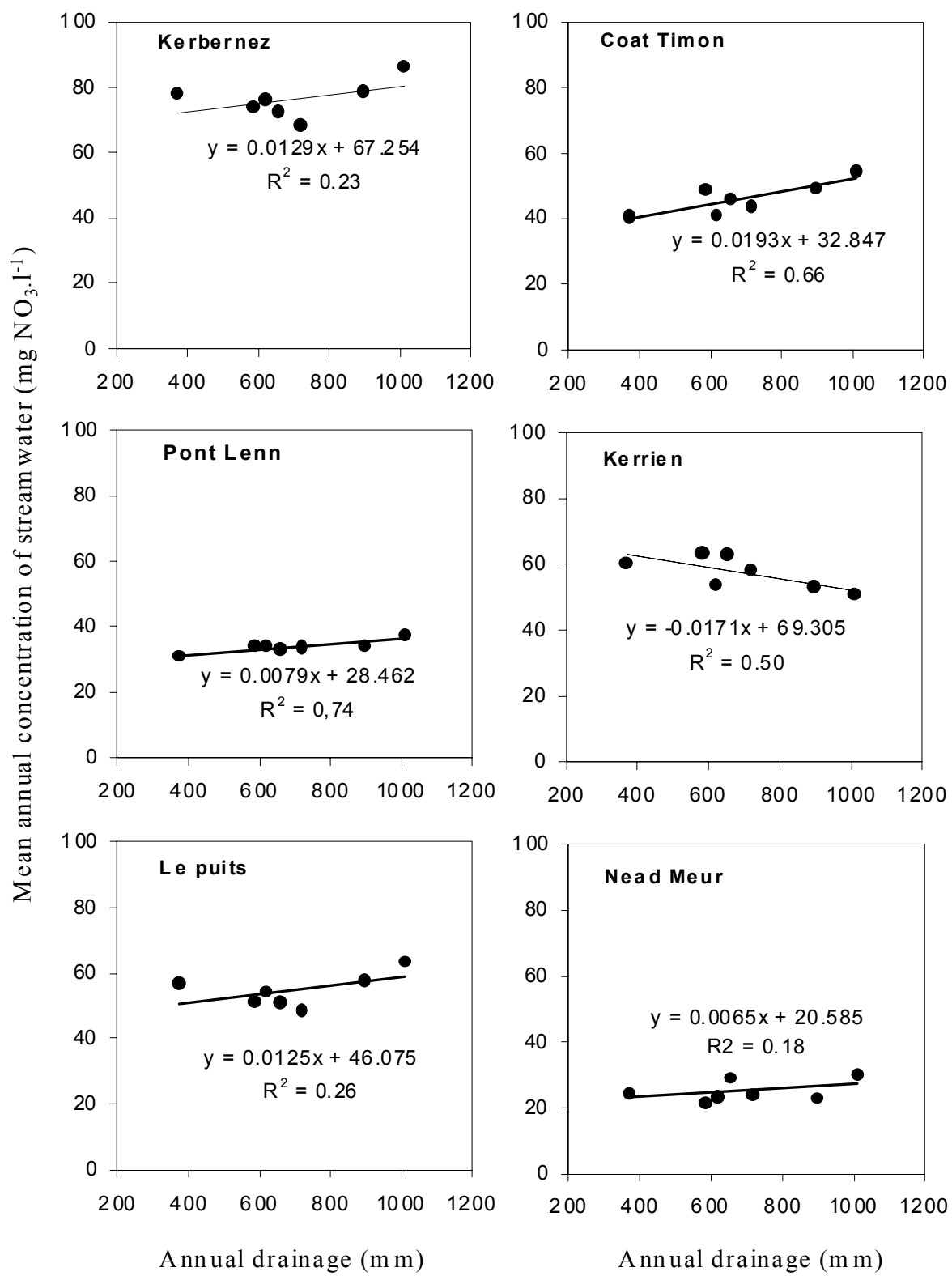

Fig 2. Nitrate concentration in streamwater $\left(\mathrm{mg} \mathrm{NO}_{3} l^{-1}\right)$ vs mean annual amount of drainage water (mm) for the six catchments.

Table 1. annual amount of $\mathrm{N}$ available for leaching as calculated from the 'corrected' budget for the whole site and for the different catchments; amount of drainage water for the following hydrological year.

\begin{tabular}{|c|c|c|c|c|c|c|c|c|}
\hline & $\begin{array}{l}\text { N availo } \\
\text { Whole } \\
\text { site }\end{array}$ & $\begin{array}{c}\text { for leaching } \\
\text { Kerbernez }\end{array}$ & 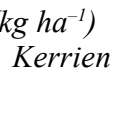 & Le Puits & $\begin{array}{l}\text { Coat } \\
\text { Timon }\end{array}$ & $\begin{array}{l}\text { Pont } \\
\text { Lenn }\end{array}$ & $\begin{array}{l}\text { Nead } \\
\text { meur }\end{array}$ & $\begin{array}{l}\text { Drainage water } \\
(\mathrm{mm})\end{array}$ \\
\hline 1993 & 88 & 42 & 111 & 73 & 110 & 97 & 30 & 1012 \\
\hline 1994 & 102 & 36 & 106 & 72 & 139 & 96 & 41 & 897 \\
\hline 1995 & 95 & 51 & 100 & 80 & 120 & 122 & 15 & 619 \\
\hline 1996 & 89 & 76 & 78 & 90 & 108 & 56 & 33 & 372 \\
\hline 1997 & 98 & 52 & 137 & 113 & 109 & 83 & 14 & 657 \\
\hline 1998 & 88 & 66 & 125 & 99 & 93 & 103 & 21 & 718 \\
\hline 1999 & 85 & 62 & 153 & 96 & 93 & 65 & 31 & 584 \\
\hline mean & 92 & 55 & 116 & 89 & 110 & 89 & 26 & 694 \\
\hline $\mathrm{cv} \quad(\%)$ & $6 .-7$ & 25.1 & 21.4 & 16.8 & 14.5 & 25.5 & 38.3 & 30.3 \\
\hline
\end{tabular}



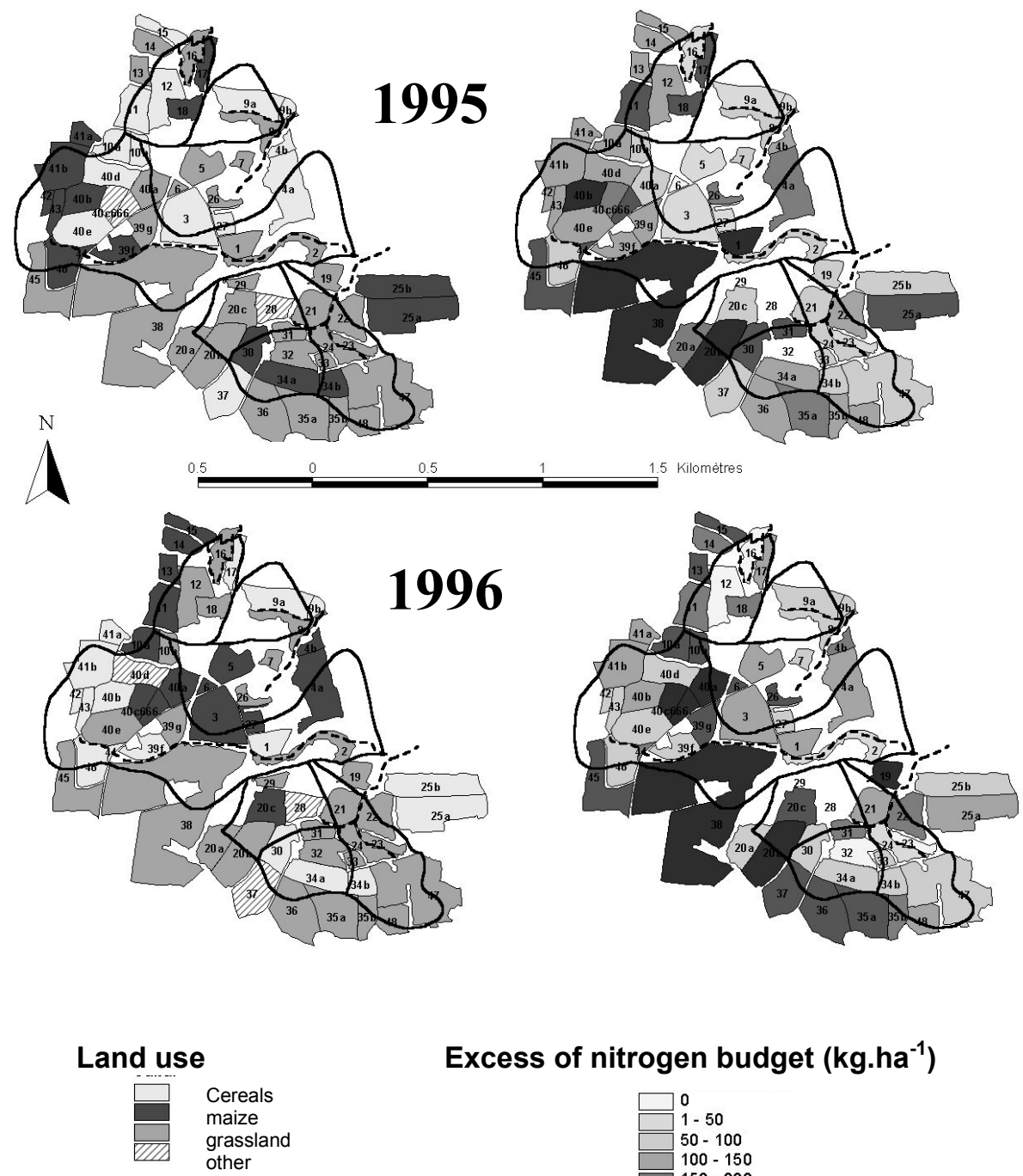

\section{Excess of nitrogen budget $\left(\mathrm{kg} \cdot \mathrm{ha}^{-1}\right)$}

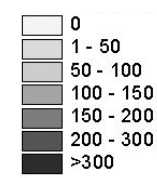

Fig 3. Example of year-to-year variations of land use (left maps) and nitrogen excess (right maps) at the catchment scale, for the years 1995 and 1996.
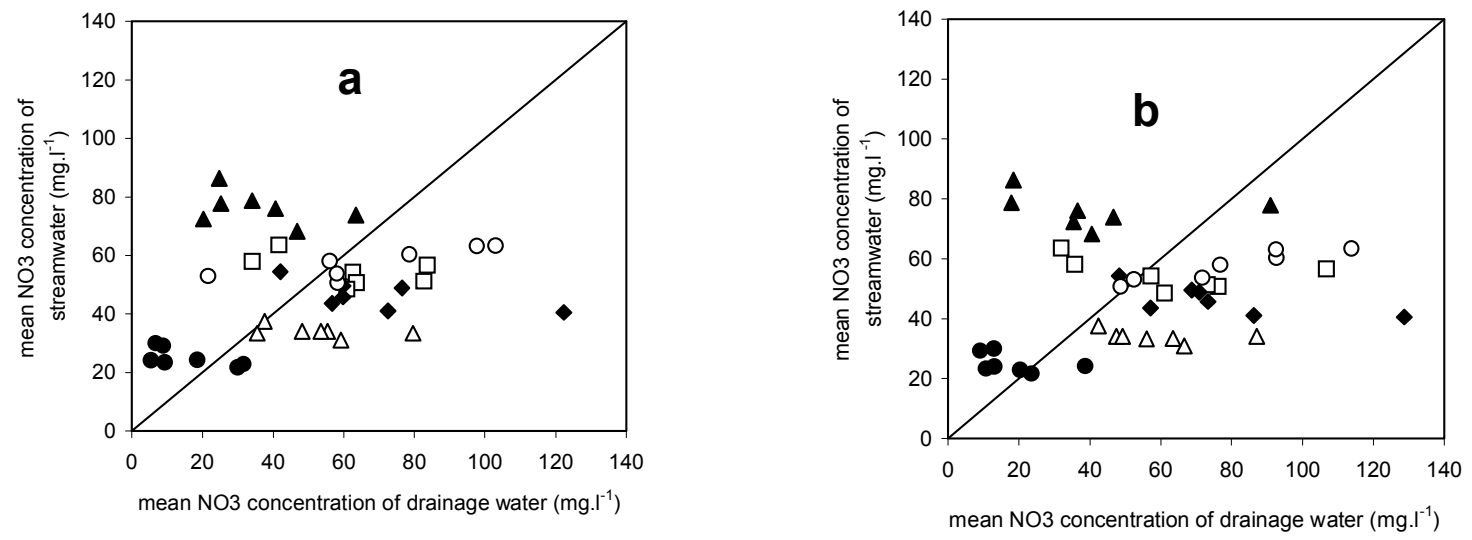

$\Delta$ Kerbernez $\square$ Puits $\bullet$ Coat Timon O Kerrien $\triangle$ PontLenn $\bullet$ NeadMeur

Fig 4. Mean annual concentration of nitrate in stream water versus mean annual concentration of nitrate drainage water, calculated from 'gross budgets' (a) and from 'corrected budgets' (b). 

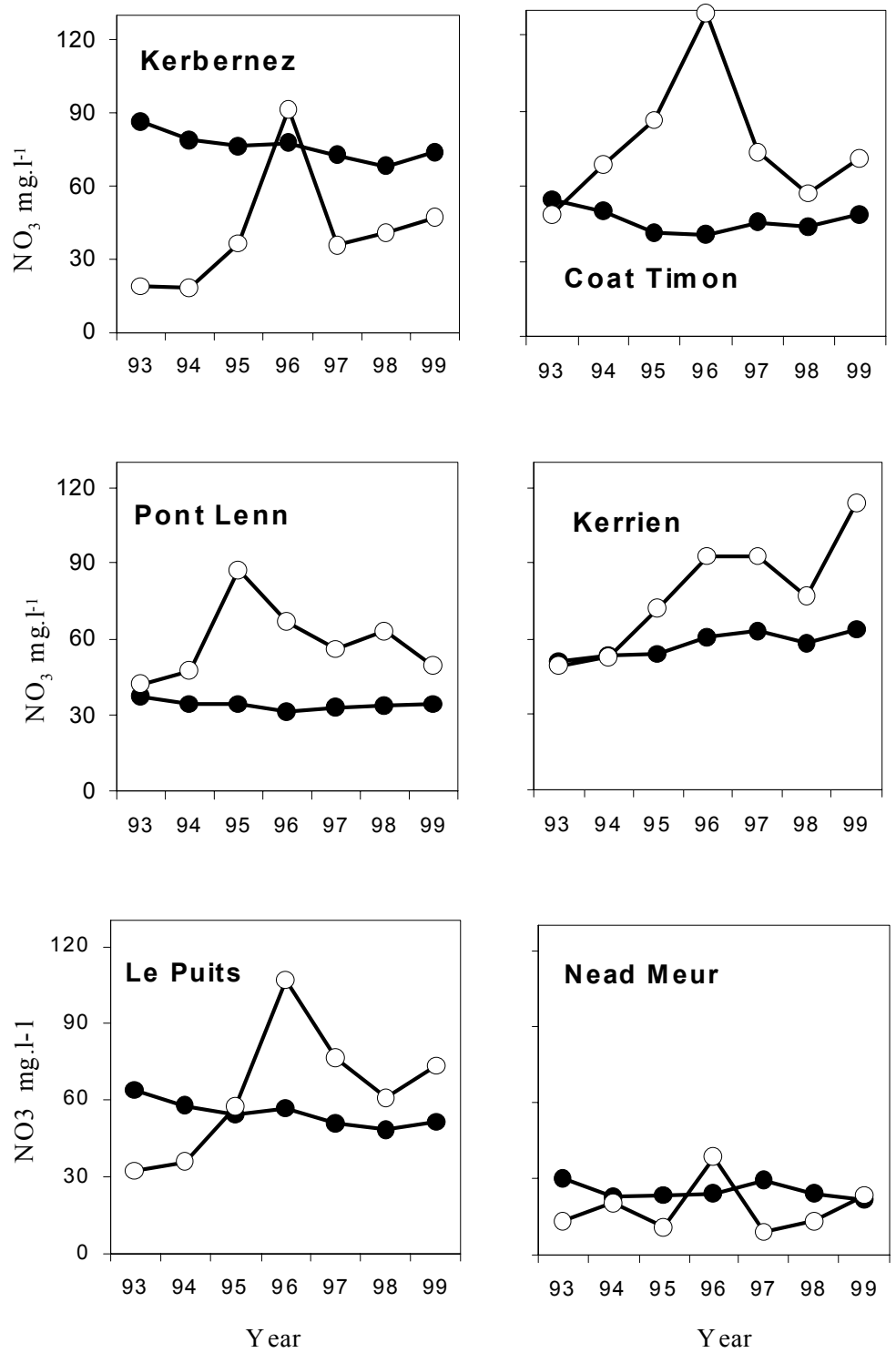

Fig 5. Variations of the mean annual nitrate concentration $\left(\mathrm{mg} \mathrm{NO}_{3} \mathrm{l}^{-1}\right)$, in streamwater (black symbols) and in the drainage water as calculated from the 'corrected budget' (white symbols) for the six catchments.

\section{Discussion and conclusion}

The results show that on an annual basis as well as for the trends over seven years, the nitrate concentration in streamwater is not related directly to the nitrate concentration in drainage water as estimated from agricultural budgets. Of course, the agricultural budgets are uncertain. Important errors arise from uncertainty in the recording of agricultural practices and lack of account of spatial heterogeneity within individual fields. Besides, the validity of the 'corrected budgets' lies in assumptions that are appropriate on a regional scale but may predict poorly the behaviour of a given field. Moreover, an annual nitrogen budget does not account for the dynamics of nitrogen availability for leaching throughout the year. A more precise estimation of the real concentration in drainage water would require direct measurements throughout the site and the use of a dynamic and distributed soil/plant/atmosphere model. However, the observed year-to-year variability in land use within each catchment is sufficient to induce marked variations in nitrate leaching. Experimental results obtained on the site, both through long-term field experiments (Simon and Le Corre, 1992) and lysimeter studies (Simon and Le Corre, 1996; Vertès et al., 1997), show that important year-to-year variations in nitrate leaching can arise for such cropping and grazing systems. Moreover, the agricultural practices on the site have changed markedly over the study period. 
Consequently, these results are strong evidence that variations in nitrate concentration in drainage water are damped out at the catchment scale. This seems not primarily due to a buffering effect of the soil organic matter, since the results with the 'corrected' budgets did not reduce the variability of the input. Rather, this buffering effect occurs during the transfer of the nitrate from the bottom of the soil to the stream, in the unsaturated zone of the weathered granite or in the groundwater.

As the nitrate concentrations in drainage water and in streamwater can exhibit opposite trends during the study period, the response time of these catchments to changes in agricultural practices may well exceed several years. This result is surprising for such small catchments, with impervious bedrock and high annual rainfall, but it is consistent with recent results obtained with different approaches. Very variable residence times for chloride (Kirchner et al., 2000) and for sodium (Neal and Kitchener, 2000) were found using spectral analysis of the input-output signal. More recently, in Brittany, Molénat et al. (2001) derived transit times greater than one year from mechanistic groundwater modelling.

These conclusions seem to contradict numerous studies that found a good agreement between land use and stream water quality. For studies on large catchments with contrasted land uses but slow land use changes, the explanation is probably a scale effect: on large catchments, the year to year variations of individual fields may compensate and the streamwater concentration is in a quasisteady state with the average annual input. However, this is not true for studies in small catchments with rapid changes, for example most of the studies of the effect of forest clearfelling on nutrient losses, especially nitrogen. They show, generally, a rapid response in the streamwater quality (less than one year) that faded within three to ten years, usually related to the changes in drainage water (Feller and Kimmins, 1984; Reynolds et al., 1992; Dahlgren and Driscoll, 1994; Durand et al., 1994; Didon-Lescot, 1996, etc.). Even if the concentrations observed in streamwater are lower than in soil water, these studies do not suggest a strong inertia of the catchment. A prime reason for this difference with the present results is that those studies were generally carried out in montane catchments with very thin soils and weathered bedrock, and very heavy rainfall: the response time in that case may actually be shorter. A second reason is that, before felling, all the catchment's waters were very low in nitrate, and the whole catchment was affected in the same way by the felling: the rapid response may be due to a contribution of subsurface flow directly to the stream, the mixing of highly concentrated soil water with groundwater low in nitrate resulting in a very marked signal in the stream chemistry. If this mechanism occurs also in the farmland catchments studied here, it will be much less noticeable, given the high background concentration of the groundwater and the high heterogeneity of the soil water chemistry, due to the variety of land use. This explanation is in agreement with the conclusions of Kirchner et al. (2000), inferring from spectral analysis a high variability in the transfer time of rainwater to the stream. It suggests the existence of different types of water and mixing processes (Ruiz et al., 2002b).

\section{Acknowledgements}

This work was supported by the European Commission (INCA project EVK1-1999-00011). The authors would like to thank Y. Quéré, M. Leroy and M. Faucheux for field and laboratory work, the Lycée horticole de Kerbernez and all its staff for facilitating access to the site and the farmers, who were always keen to provide information and allow access to the fields.

\section{References}

Aurousseau, P., Baque, M.C. and Squividant, H., 1996. Les bassins versants de Bretagne et leur charge polluante. Rapport de convention DRAF de Bretagne, Rennes, 30pp.

Béchennec, F. and Hallégouët, D., 1999. Carte géol. France (1) 50000), feuille Quimper (346). Orléans: BRGM.

Benoit, M., 1992. Un indicateur des risques de pollution nommé "BASCULE" (Balance Azotée Spatialisée des Systèmes de CULture de l'Exploitation), Fourrages, 129, 95-110.

Billen, G., Garnier, J. and Meybeck, M., 1998. Les sels nutritifs : l'ouverture des cycles. In: La seine en son bassin: fonctionnement écologique d'un système fluvial anthropisé. M. Meybeck, G. de Marsily, E. Fustec E (Eds.), Elsevier, 531-565.

Bölke, J.K. and Denver, J.M., 1995. Combined use of groundwater dating, chemical, and isotopic analyses to resolve the history and fate of nitrate contamination in two agricultural watersheds, Atlantic coastal plain, Maryland. Water Resour. Res., 31, 23192339.

Bradbury, N.J., Whitmore, A.P., Hart, P.B.S. and Jenkinson, D.S., 1993. Modelling the fate of nitrogen in crop and soil in the years following the application of ${ }^{15} \mathrm{~N}$ labelled fertilizer to winter wheat. J. Agric. Sci. Cam., 121, 363-379.

Brisson, N., Mary, B., Ripoche, D., Jeuffroy, M.H., Ruget, F., Nicoullaud, B., Gate, P., Devienne-Barret, F., Antonioletti, R., Durr, C., Richard, G., Beaudoin, N., Recous, S., Tayot, X., Plenet, D., Cellier, P., Machet, J.M., Meynard, J.M. and Delécolle, R., 1998. STICS : A generic model for the simulation of crops and their water and nitrogen balance I, theory and parametrization applied to wheat and corn. Agronomie, 18, 311346.

Burns, I.G., 1974. A model for predicting the redistribution of salts applied to fallow soils after excess rainfall or evaporation. J. Soil Sci., 25, 165-178.

Burt, T.P. and Arkell, B.P., 1987. Temporal and spatial patterns of nitrate losses from an agricultural catchment. Soil Use Manage., 3, 138-142.

Chauvin, M., Cros-Cayot, S., Houben, V. and Plet, P., 1997. Elaboration des programmes d'action de la directive nitrate en 
Bretagne, Eléments de diagnostic et de préconisations. Vol. 2, Edition CRAB.

COMIFER, 1996. calcul de la fertilisation azotée des cultures annuelles, Comifer, 59 pp.

Creed, I.F. and Band, L.E., 1998. Exploring functional similarity in the export of nitrate-N from forested catchments : A mechanistic modeling approach. Water Resour. Res., 34, 30793093.

Creed, I.F., Band, L.E., Foster, N.W., Morrison, I.K., Nicolson, J.A., Semkin, R.S. and Jeffries, D.S., 1996. Regulation of nitrate$\mathrm{N}$ release from temperate forests: a test of the $\mathrm{N}$ flushing hypothesis. Water Resour. Res., 32, 3337-3354.

Dahlgren, R.A. and Driscoll, C.T., 1994. The effects of wholetree clear-cutting on soil processes at the Hubbard Brook Experimental Forest, New Hampshire, USA. Plant Soil, 158, 239-262.

Didon-Lescot, J.F., 1996. Forêt et développement durable au MontLozère. Impact d'une plantation de résineux, de sa coupe et de son remplacement sur l'eau et sur les réserves minérales du sol. Thèse doc., Université d'Orléans, Nov. 1996, 161 pp.

Durand, P., Neal, C., Jeffery, H.A., Ryland, G.P. and Neal, M., 1994. Major, minor and trace element budgets in the Plynlimon afforested catchments (Wales) : general trends, and effect of felling and climate variations. J. Hydrol., 157, 139-156.

Edwards, A.C., Pugh, K., Wright, G., Sinclair, A.H. and Reaves, G.A., 1990. Nitrate status of two major rivers in N.E. Scotland with respect to land use and fertiliser additions. Chem. Ecology, 4, 97-107.

Farruggia, A., Decau, M.L., Vertès, F. and Delaby, L., 1997. En prairie, la balance azotée à l'échelle de la parcelle. Fourrages, 151, 281-296.

Feller, M.C. and Kimmins, J.P., 1984. Effects of clearcutting and slash burning on streamwater chemistry and watershed nutrient budgets in Southwestern British Columbia. Water Resour. Res., 20, 29-40.

Gaury, F., 1992. Systèmes de culture et teneurs en nitrates des eaux souterraines. Thèse de Docteur-Ingénieur, ENSA Rennes, 229pp.

Gaury, F. and Benoît, M., 1992. Modélisation de la qualité des eaux souterraines ; influence de l'occupation des sols en situation karstique de Lorraine. Les dossiers de la Cellule environnement. INRA, 4, 77-81.

Hénin, S., 1980. Rapport du groupe de travail 'activités agricoles et qualité des eaux'. Ministère de l'Agriculture, Ministère de l'Environnement, Paris, 58pp.

Johnes, P.J., 1996. Evaluation and management of the impact of land use change on the nitrogen and phosphorus load delivered to surface water: the export coefficient modelling approach. $J$. Hydrol., 183, 323-349.

Kirchner, J.W., Feng, X. and Neal, C., 2000. Fractal stream chemistry and its implication for contaminant transport in catchments. Nature, 403, 524-527.

Leonard, R.A., Knisel, W.G. and Still, D.A., 1987. GLEAMS: groundwater loading effect of agricultural management systems. Trans. ASAE, 30, 1403-1418.

Magdoff, F., Lanyon, L. and Liebhardt, B., 1997. Nutrient cycling, transformation and flows: implications for a more sustainable agriculture. Adv. in Agron., 60, 1-73.

Mariotti, A., 1997. Quelques réflexions sur le cycle biogéochimique de l'azote dans les agrosystèmes. In: Maîtrise de l'azote dans les agrosystèmes, G. Lemaire and B. Nicolardot (Eds.), Reims, France, 9-22.

Molénat, J., Durand, P., Gascuel-Odoux, C., Davy, P. and Gruau, G., 2002. Mechanisms of nitrate transfer from soils to stream in an agricultural watershed of French Brittany. Water Air Soil Pollut., 133, 161-183.
Montoroi, J.P., Robain, H., Schmutz, M., Martin, C., Molénat, J. and Ruiz, L., 2001. Analysis of a piezometric network using an electrical imaging survey (Kerbernez watershed, Brittany, France). In: Géophysique des sols et des formations superficielles, actes du $3^{\text {ème }}$ colloque GEOFCAN, Ed. INRA. 47-50.

Neal, C. and Kirchner, J.W., 2000. Sodium and chloride levels in rainfall, mist, streamwater and groundwater at the Plynlimon catchments, mid-Wales: inferences on hydrological and chemical controls. Hydrol. Earth Syst. Sci., 4, 295-310

Neill, M. 1989. Nitrate concentrations in river waters in the southeast of Ireland and their relationship with agricultural practice. Water Res., 23, 1339-1355.

Reynolds, B. and Edwards, A., 1995. Factors influencing dissolved nitrogen concentrations and loadings in upland streams of the UK. Agr. Water Manage., 27, 181-202.

Reynolds, B., Stevens, P.A., Adamson, J.K., Hughes, S. and Roberts, J.D., 1992. Effects of clearfelling on stream and soil water aluminium chemistry in three K forests. Environ. Pollut., 77, 157-165.

Ruiz, L., Vertès, F., Blondel, X., Journet, M. and Alard, V., 2002a. Flux d'azote et qualité de l'eau. In: A la recherche d'une agriculture durable; étude de systèmes herbagers économes en Bretagne, V. Alard, C. Béranger and M. Journet (Eds.), Ed. INRA, 273-282.

Ruiz, L., Abiven, S., Martin, C., Durand, P., Beaujouan, V. and Molénat, J., 2002b. How nitrate concentration in stream water is affected by agricultural practices in small agricultural catchments: II. Temporal variations and mixing processes. Hydrol. Earth Syst. Sci., this issue.

Simon, J.C. and Le Corre, L., 1992. Le bilan apparent de l'azote à l'échelle de l'exploitation agricole : méthodologie, exemple de résultats, Fourrages, 129, 79-94.

Simon, J.C. and Le Corre, L., 1996. Recueil de données - Site de Quimper Kerfily. In: Trente ans de lysimétrie en France, 19601990, INRA (Ed.), 205-228.

Steinheimer, T., Scoggin, K.D. and Kramer, L.A., 1998. Agricultural chemical movement through a field-size watershed in Iowa: subsurface hydrology and distribution of nitrate in groundwater. Environ. Sci. Technol., 32, 1039-1047.

Trudgill, S.T., Burt, T.P., Heathwaite, A.L. and Arkell, B.P., 1991. Soil nitrate sources and nitrate leaching losses, Slapton, South Devon. Soil Use Manage., 7, 200-206.

Turpin, N., Carluer, N., Kao, C., Piet, L., Arlot, M.P., Boerlien, P., Bioteau, T., Chaumont, C., Gouy, V., Souiller, C., Vernier, F. and Saint Cast, P., 2000. Lutte contre les pollutions en milieu rural : démarche de diagnostic des risques sur le bassin versant du Cétrais. Ingénieries, 22, 3-16.

Vertès, F. and Decau, M.L., 1992. Suivis d'azote minéral dans les sols : risque de lessivage de nitrate selon le couvert végétal. Fourrages, 129, 11-28.

Vertès, F., Le Corre, L., Curmi, P. and Nicolas, J.M., 1996. Interactions milieu-pratiques agricoles-qualité des eaux sur des bassins versants élémentaires de Bretagne occidentale. In: $1^{e r}$ Colloque interceltique d'Hydrologie et de Gestion des eaux, Rennes 8-11 juillet, Editions INSA.

Vertès F., Simon J.C., Le Corre L. and Decau M.L., 1997. Les flux d'azote au pâturage. II. Etude des flux et de leurs effets sur le lessivage. Fourrages, 151, 263-280.

Vertès, F., Laurent, F., Recous, S., Leterme, P. and Mary, B., 2001. Nitrogen mineralization under bare soils after the destruction of grazed pastures. In: Sustainable management of soil organic matter, R.M. Rees, B.C. Ball, C.D. Campbell, and C.A. Watson, (Eds.), 240-246.

Worral, F. and Burt, T. P., 2001. Inter-annual controls on nitrate export from an agricultural catchment - how much land-use change is safe? J. Hydrol., 243, 228-241 
